\title{
The Lasting Effects Of Social Media Trends On Advertising
}

Elizabeth Hoffman, Nova Southeastern University, USA

Nile M. Khanfar, Nova Southeastern University, USA

Catherine Harrington, Nova Southeastern University, USA

Lee E. Kizer, Southern Wesley an University, USA

\begin{abstract}
${ }^{1}$
Americans are exposed to an astounding number of advertising messages every day. The result of this bombardment of advertising on society is that consumers have become increasingly resistant to traditional fo rms of advertising. After spending millions of dollars on mass advertising that consumers tend to block out and ignore, marketers have re-evaluated their advertising methods and are following holistic marketing concepts that focus on customer relationship marketing and more creative, understated ads instead of in-your-face billboards and loud television segments. This paper explores social media trends, including social media opportunities and mobile marketing, and the potentially lasting effects that these trends have on advertising.
\end{abstract}

Keywords: Advertising; Social Media; Mobile Marketing; Holistic Marketing; Consumer Engagement; Communications; Targeted Messages

\section{INTRODUCTION}

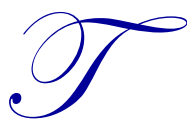

oday's westernized society is littered with ads and marketing messages and Americans are bombarded with thousands of ads every day. Visibility is important, but at what point are marketers actually reaching their customers instead of trying to keep up with one another? Instead of spending millions of dollars on mass marketing that consumers continue to block out, marketers should focus more on tailored messages and relationship building with customers. A key component of this type of marketing is targeting the right people with the right message through social media.

\section{THE HISTORY OF MARKETING CONCEPTS}

Marketing is an essential activity for any successful organization. Marketing is the process of communicating value to customers and "meeting needs profitability" (Keller \& Kotler, 2009, p. 5). Marketing is both an art and a science and is ever changing to meet the needs of business. The marketing concept started in the mid-1950s when companies began to focus more on customers by developing products that might meet their needs, rather just mass producing what already existed. The advent of television as a new media also played a role. The marketing concept was not always as widely accepted as it is today. Prior to the 1950s and emergence of service industries, the production concept was more commonly used. The production concept was the be lief that when goods are widely available and inexpensive, people will buy them (Keller \& Kotler, 2009). Understandably, the production concept was strongly followed during the industrial age. The product concept closely followed the production concept in popularity with the idea that consumers would prefer higher quality products that are priced competitively.

The selling concept emerged after the production and product concepts and encompasses hard and aggressive selling. The belief under the selling concept is that consumers will not buy a product unless they are pushed to do so. This is a risky concept and not one that is practiced commonly today. Today, the marketing concept and holistic marketing concept are more popular among organizations. The marketing concept embraces the idea of consumer

\footnotetext{
${ }^{1}$ This manuscript was original published in the Journal of Business \& Economics Research 8(11), 73-80. Due to high download rates this manuscript has been reprinted.
} 
engagement and believes that the right products must be delivered for the customers and not the other way around (Keller \& Kotler, 2009). The holistic marketing concept takes the marketing concept one step further where essentially marketing is done from every angle (e.g., internal and external to the company) and with every person (i.e., all relationships including the consumer and supply chain) under the holistic marketing concept.

Even though the marketing and holistic marketing concepts are more widely accepted by organizations, the selling concept is what is more commonly seen or at least perceived by consumers. You cannot drive down the highway today, turn on the radio, open a magazine, or even buy a soda from a nearby vending machine without seeing or being exposed to an advertisement. Even when marketers are segmenting the market and only advertising their product in areas where they believe their targeted demographic will see them, they still have to compete for their customers' attention. In 2006, it was believed that the average American was exposed to 5,000 ads a day, and that number has only continued to grow (Johnson, 2006). Nothing is off limits to advertisers; cross promotions, sponsorship opportunities, banners, and product placements have lead to consumers feeling overwhelmed with ads. This feeling leads to the consumer's desire to shut out unwanted messages. While advertisers long for a time when reaching the consumer was easier and work to reinvent new ways to reach their customers, consumers continue to find new ways to avoid them.

\section{MARKETERS RESPONSE TO CONSUMERS RESISTANCE}

The desire to avoid ads is evident nearly everywhere. Radio stations promote commercial free listening, and Home Box Office (HBO) boasts commercial free programming that consumers find so desirable that they pay extra for it. Cities are establishing new codes to prevent banner placements on buildings, and new products are being developed to aid consumers in their quest to get rid of unwanted ads. One of the more successful technological advances to date is TiVo. TiVo is a recording system that debuted in 1999 and allows consumers to record their favorite shows and skip commercials entirely. All these advancements are evident of consumers' behavior changes.

As a result of consumer behavior changes, the selling concept is, understandably, no longer effective. In addition, the idea of aggressively selling to consumers through flashy advertisements is no longer pursued, at least not by the savvy marketer. As consumers become more resistant, advertisers must become more subtle and subliminal. To adapt to this continued resistance from consumers, there has been "a recent mini-trend of ads that muffle senses instead of attacking them" (Stevenson, 2010, para. 1). One of the more subtle ads being introduced right now is an advertisement for Symbicort, an asthma medication. The ad is quiet and only shows the outline of a woman who remains hidden for the duration of the ad, very unconventional for advertisers these $\mathrm{d}$ ays. The trend is followed by John Hancock, a financial firm that launched a series of ads beginning in 2008 that depict professionals emailing and texting one another about financial security while in a quiet location such as a park or coffee shop. Vice president for John Hancock, Jim Bacharach, says the ads were developed as a provocative marketing strategy after realizing that people no longer watch television (Stevenson, 2010).

In a multi-tasking, over-stimulated society, people no longer have their attention solely on one activity. The television might be on, but it is competing for viewers' attention with magazines, computer emails, texting, and more (Stevenson, 2010). As a result, John Hancock attempted to cut through the noise by turning down the noise on its ads. Hancock has also realized that with the invention of TiVo and other advancements to shield the consumer from unwanted ads, it needed to focus on live sporting events in order to reach target customers through television. The move was incredibly tactical on the part of John Hancock since it knew consumers are not likely to prerecord live sports events or watch them at a later time online.

Another option for marketers is to make their advertisement more appealing and entertaining with video games and shows, essentially "making them part of the entertainment instead of a break from the entertainment" (Johnson, 2006, para. 7). For example, one company, Submedia, actually places ads in underground transportation systems, and these ads come to life when a train moves by (Johnson, 2006). The idea is to create something unique, different, exciting, and entertaining in an effort to remain part of the consumer's memory.

These trends, of course, suggest that traditional mass media advertising is not the way of the future. In fact, the number one communication channel for which advertising trends are expected to grow is online. In 2009, 
Publishing Executives contacted an independent research company, Readex Research, to uncover upcoming advertising trends. Over half of the 175 respondents expected print advertising revenue to drop, while 29 percent of respondents stated that online sales remained their fastest-growing segment (Skodzinski, 2009). While not predicted to be the top revenue generator for the publishing industry, online and web revenue is certainly growing at an astronomical rate; therefore, publishers and advertisers have little choice but to take notice. The days of mass marketing to all consumers are long gone, and marketers are now forced to think more strategically about their objectives then they have in years past.

It is important for marketers today to stand out from all the media clutter and find their niche, which is a marketer's "more narrowly defined customer group seeking a distinctive mix of benefits" (Kotler \& Keller, 2009, p. 209). In order to do this, marketers must segment the market by defining customers that share similar values. Segmenting the market appropriately allows marketers to reach people who can ignite the fuse of interest among others. This is essential to starting trends among potential and current customers.

\section{TARGETING THE RIGHT PEOPLE WITH THE RIGHT MESSAGE}

In the best selling marketing book, The Tipping Point, Gladwell (2000) suggests that big trends are started by small groups of people that have the power to communicate with, inform and influence one another in society. Gladwell found that throughout history, the start and success of social, political and fashion trends can all be traced back to specific types of people who can be categorized as connectors, mavens, or salespeople. The people that fall into these special categories are capable of starting trends or ending them. As a result, it is vital for marketers to unders tand the connectors, mavens, and salespeople and pay attention to them.

Connectors can help marketers communicate with the right people. Connectors are a special group of people that have a gift of bringing people and ideas together and in a sense connecting people together (Gladwell, 2000). Marketers must tune into the fact that connectors have a prevalent place in social media forums and new media technology. Any new media technology that has the ability to bring people together, will have people who function as connectors and are the ones that move and steer people into directions and avenues of interest to them in the social media. This is critical for marketers to understand.

Another key group of people that Gladwell (2000) focuses on are the mavens. Mavens are the ones that essentially soak up information. They want to know the best deal and tell everyone about it (Gladwell). They are credited with having the ability to start word-of-mouth trends with their charisma and social skills. Again, this is important for marketers to note when looking into buzz marketing. For example, if marketers want to create a buzz about a new product, they need to target the mavens. Due to their thirst for knowledge, mavens will be those more likely to sign up to receive special informational email alerts and other selective services. Creating a desirable place, relationship, and system that provides selected people with coveted information will reel in the mavens. A buzz in the market starts when mavens tell their friends about the special information they are receiving. Mavens, in particular, will remain loyal to companies that peak their interest on the latest product or newest upgrade. Letting them know first fulfills the self-esteem need of the maven, who wants to feel important.

Of course, there are always the salespeople, and they cannot be ignored. These people are individuals that have the ability to convince and sell people on new ideas. It is important to note that salespeople are not hard core salesmen most people envision or even people that promote the selling concept (Gladwell, 2000). Salespeople are often identified by their ability to persuade others; however, Gladwell describes the art of selling as an elegant and harmonious dance. Through this dance, others are brought into the rhythm leaving the salesperson with the ability to control the relationship and interaction (Gladwell).

Both the mavens and salespeople have the unique ability to be influencers in a consumer's decision -making process. The word of mouth marketing campaigns that they can ignite can have huge ripple effects and create a wave of interest and trends. In fact, "influential customers within branded customer communities can increase the effectiveness of word-of-mouth marketing programs by as much as 50 percent" (Business Wire, 2009, para. 3). The simple fact is these mavens, salespeople, and even connectors have the ability to produce a high return on investment. In this way, companies obtain $80 \%$ of their potential sales by targeting fewer than $5 \%$ of the audience 
(Business Wire, 2009). Not only does targeting the right group of people save companies advertising expenses, but it may also dramatically improve their marketing productivity.

Before marketers can target the right people for their word-of-mouth marketing campaigns, they have to create a certain level of stickiness, i.e. "there is a simple way to package information that, under the right circumstances, can make it irresistible" (Gladwell, 2000, p. 132). Creating sticky messages is a challenge in today's over-stimulated society, but it can be done. To keep a message sticky, Gladwell suggests creating a subtle but significant change. An example of a subtle change from the norm is the toned down television ads recently launched by John Hancock, Symbicort, and many others. Some of the smallest elements can cause the most stickiness and of course, the context of the message must be powerful. Once the message is crafted, the marketers must find the appropriate platform to introduce the message to key people. Of course, a message can be sticky, but if it is not relevant, the message will not be received or utilized properly. Therefore, it is important for marketers not only to create a memorable message but also to keep the information relevant and useful to the consumer.

\section{MARKETERS MUST EXPLORE NEW MEDIA PLATFORMS}

The platform used to introduce marketing messages to the three key movers identified by Gladwell (2000) must be well thought out. Television, radio, and even Internet advertising all have the ability to reach large numbers of people in a short amount of time, but this type of advertising is too general to target connectors, mavens, and salespeople. A more holistic, comprehensive relationship marketing strategy must be utilized to target these people. The idea of relationship marketing is to "build mutually satisfying long-term relationships with key constituents in order to earn and retain their business" (Keller \& Kotler, 2009, p. 20). To build and sustain such a relationship, marketers need to understand and respond to customer needs and goals. The emergence of social networking media, such as Facebook and Twitter, has opened the door to a million possibilities for marketers. The ability for these social media to segment the market automatically is one reas on why they are so effective. Consumers can customize their Facebook and social networking pages so that the information they receive is relevant to them Social media networks also allow marketers more easily to reach connectors and mavens (for spreading the word) and salespeople (to convince others to jump on the social networking bandwagon). One very clear and successful example of the use of social media for marketing was the 2008 presidential election.

The presidential election in 2008 was the first election in history where social media played a major role. President Barack Obama launched a very aggressive and successful social networking campaign. Not only did Obama have a very successful and comprehensive Facebook site and Twitter account, but the email addresses he obtained via the social networking sites enabled successful email campaigns that raised money and motivated the electorate. YouTube was also used to great success. Obama and McCain videos drew 1.45 billion views on YouTube during the presidential campaign (Learmonth, 2008). The results were ground breaking and in September, 2008 "YouTube became the biggest search engine after Google and had 59 percent more visitors than in the previous year, according to ComScore" (Learmonth, para. 14). Clearly, the rise of social media forums had a profound impact on the presidential election for 2008 , and that trend will likely continue.

The rise in social media advertising also marks a continued trend by marketers to establish more intimate relationships with their customers. In the digital age, more and more people in western cultures are finding new ways to connect with like-minded individuals. Citizens in developed countries are more intere sted in satisfying their needs for greater esteem and self-actualization (Keller \& Kotler, 2009). The rise in social media forums reflects this trend. Many people have their own personal website where they fill out information about themselves, post pictures of themselves, create their own blogs, and upload their own videos. It is important for advertisers to understand the importance of self-esteem and self-actualization in such highly individualistic societies and design appeals that satisfy these higher personalized needs. While developing targeted marketing programs may be more time consuming and cost more money to develop, the payoffs can be greater and in many cases, the leg work has already been done. Many social networking sites give consumers the ability to personalize their preferences and information, thus segmenting consumers for marketers.

Of course, one way to enhance the consumers' experience is to put sufficient time and effort into social media campaigns. A company cannot let its social networking site remain stagnate, and it cannot inundate the consumer 
with marketing messages or the consumer will simply shut it out. One mistake that many marketers are making today is utilizing social media forums without really developing a strategy. Social media is all about the conversation and so marketers need to keep this in mind and participate in the conversation by talking with their customers and not at them. When one is participating in social media, you are being asked to "to be active, reactive and proactive conversationalists" (Meyer, 2009, par 4). A business or marketer could always ignore the photos, blogs and conversations going on around them, but the potential benefits of being involved will be lost. The marketer has to bring value to the conversation in order to take anything positive away from the experience.

It is interesting to note that this idea of social, conversational marketing media has been around for decades and did not just emerge with the Internet. One of the more successful social media strategies before the emergence of the Internet was the launch of the Michelin Guide. While Michelin is more commonly known today for meeting travel needs, back in 1900 it was struggling to find its footing as a tire company. Brothers Edouard and Andre Michelin wanted to build their car and bicycle tire brand and realized that they could engage their potential customers by producing a travel guide that used independent inspectors to rate the quality of restaurants and hotels (Madden, 2010). The guide focused more on food than it did on tires, as that was more relevant to their customers' interests. The travel guide, which also promoted Michelin tires, engaged Michelin's potential customers in the process and became an overwhelming success. Its success is proof that conversation, participation, and customer relationship marketing are the building blocks for a successfulmarketing and business strategy.

Today, digital media are dominating the world. Facebook currently boas ts over 400 million users and continues to grow at an astounding rate (Crunchbase, 2009). Twitter also exploded in 2009 and attracts "more than seven million unique visitors" (Armano, 2009, para. 1). What is even more impressive is that Twitter reached its 10 billionth tweet on March 4, 2010, doubling the amount of tweets in just four months (Patterson, 2010).

Twitter has been used for marketing in a number of unique ways. For example, a restaurant owner may have a Twitter account and could post a message on Twitter informing people that they are eligible to receive a free drink from the restaurant if they show the Twitter message to the bartender at the restaurant. The restaurant owner is able to generate interest in his or her restaurant through a free advertising method. Marketing messages have to be strategic, relevant, and measurable. Examples such as the Twitter marketing by the restaurant owner show that success is related to the ability of the marketer to personalize and deliver the message so that the consumer welcomes it.

Marketers are finding that interactive and targeted marketing are the keys to success and that traditional advertising is essentially a waste of money (Bernoff, 2009). Six out of 10 marketers recently surveyed by Forres ter Research stated that they would increase their budget for interactive marketing by shifting away from traditional advertising (Bernoff). "The result is that digital, which will be $12 \%$ of overall advertising in spend in 2009, is likely to grow to about $21 \%$ in five years" (Bernoff, para. 6).

Not surprisingly, marketers have been taking notice and are using the tailored social networking forums to reach consumers in a more personalized way. As a result, social media ad sales are expected to grow from \$716 in 2009 to $\$ 3$ billion in five years (Bernoff, 2009). Figure 1 depicts the growth of interactive marketing over the next five years from Forrester's Interactive Advertising Models as shown below.

Figure 1 also shows that a large increase in mobile marketing spending is expected (CAGR 27\%). The use of smartphones, like iPhones and Blackberries, allows consumers to be connected to their favorite social media outlets 24 hours a day. Most organizations, from auto insurance companies to clothing designers, not only have a website, but they also have a Facebook page, Twitter account, and an iPhone application. The key to being effective at utilizing these social media tools is by not appearing to advertise to the consumer, but instead to build a relationship with the consumer and establish a level of trust.

As digital media becomes more popular, advertising through digital media also becomes more effective. Facebook, Twitter, and iPhone accounts have mass email distribution capabilities to export events, but businesses are catching on. For example, "the New York Times iPhone application recently added a sharing functionality which allows a user to easily broadcast an article across all networks, such as Facebook and Twitter" (Armano, 2009, para. 7). 
Websites, like Posterous, allow users to set up an account that immediately transports all blog information, photos, events, and updates to the users' social networking accounts like Facebook, Twitter, YouTube, and personal websites. Updates can even be made directly from one's smartphone allowing the user never to feel out of touch for a moment. This is an extremely useful tool of which marketers should be aware. Through such technology, marketers may literally be in touch with their customers 24 hours a day and have direct access to them. The ability for marketers to communicate directly with their consumers and vice versa represents the fluidity of social media. The result is that customers are able to make suggestions that, in turn, are relayed to product development and customer support more quickly (Maddox, 2010).

Figure 1. Interactive Marketing (2009-2014)

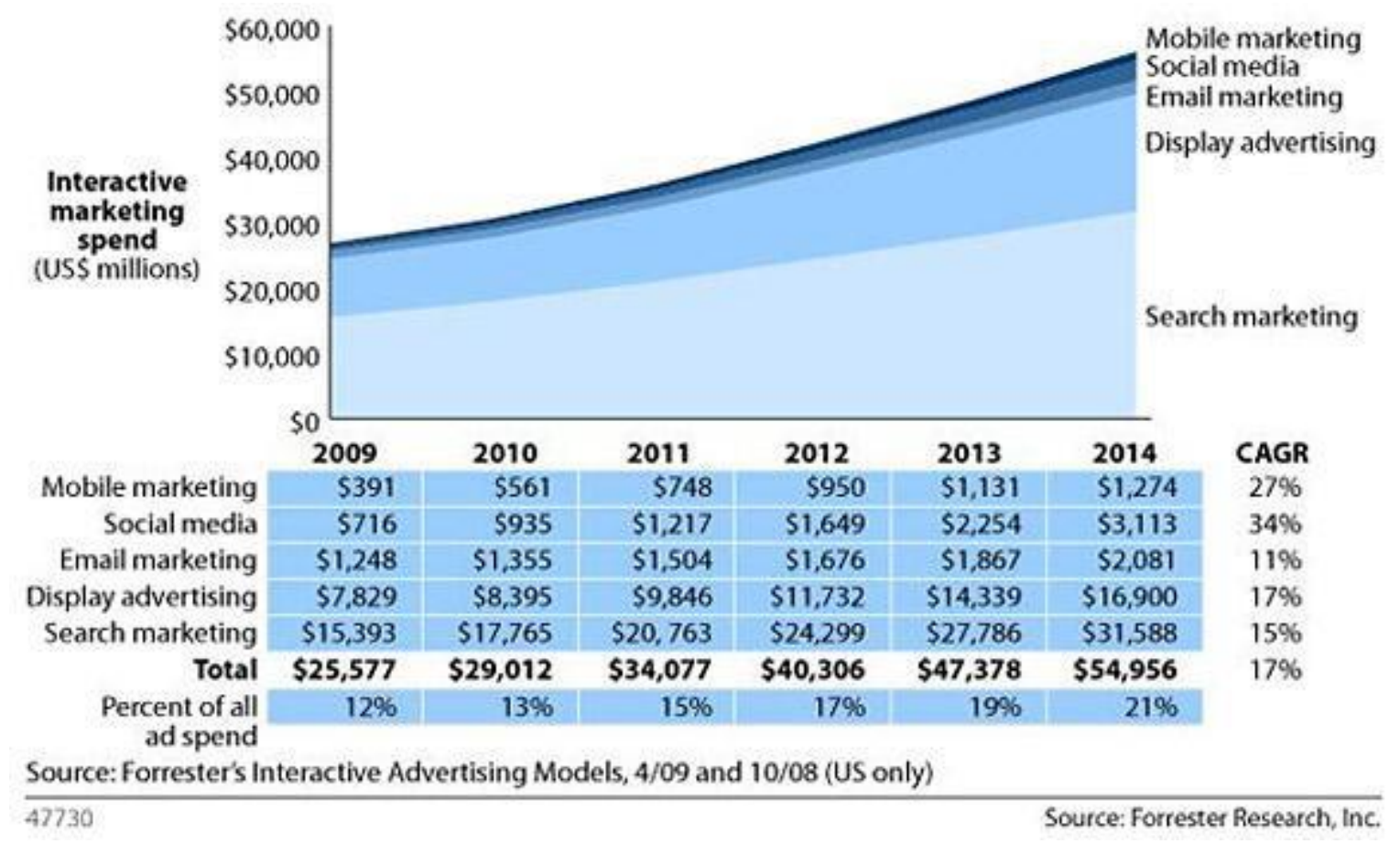

\section{CONCLUSION}

There is no doubt that technology will continue to advance at a skyrocketing rate making it impossible for marketers to predict every marketing medium that they should enter in the coming years. The important thing is that marketers should remain on the lookout and be ready to jump into new opportunities. One way for marketers to keep their finger on the pulse is by developing and maintaining relationships with innovative leaders, such as connectors, mavens, and salespeople that Gladwell (2000) describes. The importance of two-way communication cannot be understated as the feedback from these key people will help marketers to be aware of new popular mediums and new consumer trends.

Social media is all about answering the basic human question on how we can help one another (Orr, 2009). That basic notion of communication will prosper and should remain the focus as marketers learn to navigate the social media world. In conclusion, marketers are encouraged to keep the lines of communication open with consumers in order to create real value for their customers. After all, that is what marketing and social communication is all about - creating value for everyone. 


\section{AUTHOR BIOGRAPHIES}

Elizabeth Hoffman (Wright) is a marketing and business professional working in the fields of technology, startups, retail, economic development, brand management and much more. She holds a Masters in Business Administration from Nova Southeastern University, a Bachelor of Arts in Communications from Michigan State University, and a Digital Media \& Marketing Certificate from New York University. She also works with a variety of non-profit organizations, such as Unleashed, a leadership development program designed for adolescent girls and the U.S. Embassy in Abidjan Cote d'Ivoire where she hosted several leadership development classes geared toward young women. Elizabeth continues to write in her spare time and dabbles in projects ranging from startups, to travel blogs, women entrepreneurship and much more. She currently resides in New York City.

Nile M. Khanfar is Assistant Dean of the Pharmacy Program College of Pharmacy, Nova Southeastern University, Palm Beach Gardens, Florida. He is also an Associate Professor in the Department of Sociaobehavioral and Administrative Pharmacy. He also serves as an Adjunct Professor at the H. Wayne Huizenga School of Business and Entrepreneurship at Nova Southeastern University, Fort Lauderdale, Florida. Dr. Khanfar earned his MBA and his Ph.D., in Pharmacy Administration from the University of Louisiana at Monroe. He has published more that 60 articles and abstracts and presented over 30 presentations in national and international conferences. Dr. Khanfar's research focus include topics in Management leadership, strategic management/marketing business cases, and direct-to-consumer advertising of prescription medication and its influence on their behavior.

Catherine A Harrington, PharmD, PhD received both her Doctor of Pharmacy and Doctor of Philosophy in Health Services Organization and Policy from the University of Michigan. She is currently an adjunct professor at Nova Southeastern University, College of Pharmacy, Ft. Lauderdale, FL. She has held executive positions in pharmacy benefit management and healthcare consultancy businesses. Her research interests include topics in the fields of business, healthcare policy, and drug safety. She has numerous publications in peer-reviewed medical and pharmacy journals.

Lee E Kizer is a Profess or of Business at Southern Wesleyan University. He earned his MBA from the University of Arkansas and his Doctor of Science in Human Resource Management from Nova Southeastern University. His publications include cross cultural case studies as well as research in employee performance as a result of training. Dr. Kizer's research interests include topics in the areas of employee motivation, employee retention, compensation and job analysis and design. As a former Special Agent for the Federal Bureau of Investigation (FBI), he continues to perform security contract work for the federal government with the Department of Energy, the Department of Defense and the Department of Justice.

\section{REFERENCES}

Armano, D. (2009, November 2). Six social media trends for 2010. The Conversation. Retrieved February 19, 2009 from http://blogs.hbr.org/cs/2009/11/six_social_media_trends.html.

Bernoff, J. (2009, July 20). Advertising will change forever. Advertising Age. Retrieved February 19, 2009 from http://adage.com/digitalnext/article?article_id=138023.

Buiness Wire. Research Reveals Word-of-Mouth Campaigns on Customer Networks Double Marketing Results. (27 October). Retrieved March 5, 2010, from ABI/INFORM Dateline. (Document ID: 1887268081).

CrunchBase (2009). Facebook. Retrieved February 19, 2009 from http://www.crunchbase.com/company/facebook.

Frommer, D. (2009, April 8). Facebook now the fifth-largest country in the world. Silicon Alley Insider. Retrieved February 19, 2009 from http://www.businessinsider.com/facebook-now-the-fifth-largest-country-in-the-world-2009-4.

Gladwell, M. (2000). The tipping point: How little things can make a big difference. New York: Little, Brown, and Company.

Keller, K., \& Kotler, P. (2009). Marketing management (13th ed.). Upper Saddle River, New Jersey: Pearson.

Johnson, C. (2006, September 17). Cutting through advertising clutter. CBSNews. Retrieved February $19^{\text {th }}, 2010$ from http://www.cbsnews.com/stories/2006/09/17/sunday/main2015684.shtml.

Learmonth, M. (2008, November). One-way media lost the election as cable, interactive dominated. Advertising Age, 79(42), 1,56. Retrieved March 5, 2010, from ABI/INFORM Global. (Document ID: 1594819431).

Madden, R. (2010, February). Marketing strategy: Stop putting social media cart before content horse. Marketing Week,11. Retrieved March 5, 2010, from ABI/INFORM Global. (Document ID: 1960060711).

Maddox, K. (2010, January). Optimism, accountability, social media top trends. B to B, 95(1), 1,24. Retrieved March 5, 2010 , from ABI/INFORM Global. (Document ID: 1951086801). 
Meyer, M. (2009, November). Give more and get more out of social media. Communication World, 26(6), 48. Retrieved March 5, 2010, from ABI/INFORM Global. (Document ID: 1896728361).

Orr, W. (2009, December). So much to learn from the Battle of Big Thinking. Campaign, 8. Retrieved March 5, 2010, from ABI/INFORM Global. (Document ID: 1935956171).

Patterson, M. (2010, March 5). 10 billionth tweet comes and goes, unavailable to the world at large. Palm Beach Post. Retrieved, March 5, 2010 from http://blogs.palmbeachpost.com/techtonic/social/10-billionth-tweet-expected-this-evening-whatwill-it-say/

Skodzinski, N. (2009, June). Your guide to ad revenue trends. Publishing Executive, 24(5), 20-24, 49. Retrieved March 5, 2010 , from ABI/INFORM Trade \& Industry. (Document ID: 1788704961).

Stevenson, S. (2010, February 1). Soft Sell: Why quiet understated TV ads are so effective. Slate. Retrieved on February $1^{\text {st }}$, 2010 from http://www.slate.com/id/2242966/?GT1=38001. 